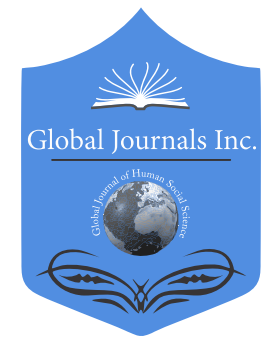

\title{
Ecological Status, Natural Productivity, Physico-Chemical and Biological Factors Controlling Productivity in the Bow Lake of Bansadaha, Burdwan
}

By Md. Tanushree Chakrabarti \& Padmanabha Chakrabati

The University of Burdwan

Abstract- The basic understanding of the limnology, productive potentials, and fish productions of beel (water body) is essential for the sustainable development at Bansdahabeel in Burdwan. The area of Bansdahabeel is 26-hectare having depth 1.75 to $5.5 \mathrm{~m}$. An investigation was conducted on the ecology of the beels, productivity, plankton and macrophytes. Transparency value was low during summer and the $\mathrm{pH}$ was slightly alkaline. The monthly mean values of dissolved oxygen were somewhat lower in this closed beel (water body). The nitrate values were higher in summer and lower during the monsoon period. The soil contains $93 \%$ of sand. Among the plankton, community, phytoplankton formed the main portion of the total plankton. Cyanophyceae was the major contributor among the phytoplankton as Chlorophyceae was the second largest group. The monthly mean value of the zooplankton population was $417.22 \mathrm{\mu l}^{-1}$ in Bansdahabeel. The beel harbours mixed population of macrophytes with the dominance of submerged plants throughout the year. Fish production was recorded to $1159.83 \mathrm{~kg} / \mathrm{ha} / \mathrm{yr}$. However, the production of carps was much higher than the miscellaneous fishes.

Keywords: oxbow lake, wetland, beel, macrophyte, productivity, plankton.

GJHSS-B Classification: FOR Code: 040699

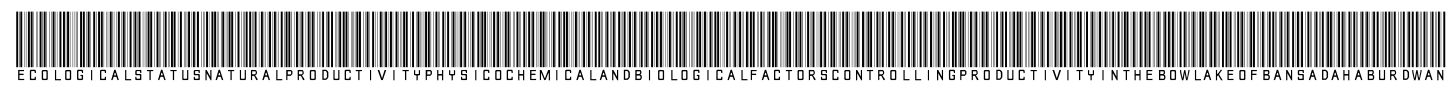

Strictly as per the compliance and regulations of:

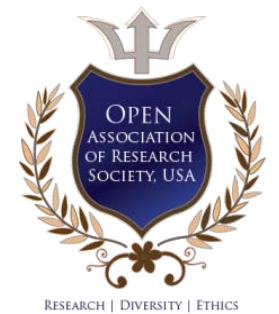

(C) 2020. Md. Tanushree Chakrabarti \& Padmanabha Chakrabati. This is a research/review paper, distributed under the terms of the Creative Commons Attribution-Noncommercial 3.0 Unported License http://creativecommons.org/licenses/by-nc/3.0/), permitting all non-commercial use, distribution, and reproduction in any medium, provided the original work is properly cited. 


\title{
Ecological Status, Natural Productivity, Physico- Chemical and Biological Factors Controlling Productivity in the Bow Lake of Bansadaha,
} Burdwan

\author{
Tanushree Chakrabarti $^{\alpha}$ \& Padmanabha Chakrabati ${ }^{\sigma}$
}

Abstract-The basic understanding of the limnology, productive potentials, and fish productions of beel (water body) is essential for the sustainable development at Bansdahabeel in Burdwan. The area of Bansdahabeel is 26-hectare having depth 1.75 to $5.5 \mathrm{~m}$. An investigation was conducted on the ecology of the beels, productivity, plankton and macrophytes. Transparency value was low during summer and the $\mathrm{pH}$ was slightly alkaline. The monthly mean values of dissolved oxygen were somewhat lower in this closed beel (water body). The nitrate values were higher in summer and lower during the monsoon period. The soil contains $93 \%$ of sand. Among the plankton, community, phytoplankton formed the main portion of the total plankton. Cyanophyceae was the major contributor among the phytoplankton as Chlorophyceae was the second largest group. The monthly mean value of the zooplankton population was $417.22 \mu \mathrm{l}^{-1}$ in Bansdahabeel. The beel harbours mixed population of macrophytes with the dominance of submerged plants throughout the year. Fish production was recorded to $1159.83 \mathrm{~kg} / \mathrm{ha} / \mathrm{yr}$. However, the production of carps was much higher than the miscellaneous fishes. This study may be helpful in optimum utilization and sustainable management of the beel. The management and conservation are essential to ensure a higher fish yield.

Keywords: oxbow lake, wetland, beel, macrophyte, productivity, plankton.

\section{InTRODUCTION}

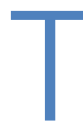
he availability of protein-rich food has been particularly constrained. Fish is recognized as the most important and easily digestible animal protein and with the available resources, it can play a great role in fulfilling the protein requirement. Apart from promoting aquaculture, the country will have to focus her attention to achieve optimum sustainable yield from wetlands, reservoirs, etc. The oxbow lakes were created in the process when young meandering rivers grew old, straightened their course leaving the erstwhile bend and deepest part separated from the main flowing river course. The separated lotic became stagnant, i.e. lentic water body separated from the river. The oxbow lakes or lakes constitute boundless and varied fisheries

Author $\alpha$ : Department of Geography, The University of Burdwan, Burdwan- 713104, West Bengal, India.

Author o: Fisheries Research Laboratory, Department of Zoology, The University of Burdwan, Burdwan-713104, West Bengal, India.

e-mail:mainak.bio@gmail.com resources. These water bodies called oxbow lakes. Oxbow lakes have to be recognized and distinguished from other ecosystems by the ecological characteristics alone for their proper management (Sinha, 1997). The closed beels are water bodies that have lost connections with the main river generally due to strengthening of river embankment. The fishery constituted by miscellaneous fishes (Yadav, 1987). In closed lakes, stocking is the mainstay of management. A production rate up to $1000 \mathrm{~kg} / \mathrm{ha} / \mathrm{yr}$ is attainable from floodplain lakes when subjected to scientific management against production to $100 \mathrm{~kg} / \mathrm{ha} / \mathrm{yr}$. under traditional management (Sinha, 1998, 2001).

The present study has been contemplated from 2017 to 2018 in Bansadaha closed system located in the district of Burdwan, West Bengal to ascertain ecological status, natural productivity, fishery potential, physico-chemical and biological factors controlling productivity.

\section{il. Materials and Methods}

The investigation was carried out in closed type beel of Bansadaha during the period from January 2017 to December 2018. The area of Bansadaha beel is 26 hectare lies between latitude $23^{\circ} 21^{\prime}$ to $23^{\circ} 20^{\prime} 43^{\prime \prime} \mathrm{N}$ and longitude $88^{\circ} 17^{\prime} 45^{\prime \prime}$ to $88^{\circ} 20^{\prime} \mathrm{E}$. Fluctuation in water depth on an average ranged in Bansadaha from 1.75 to $5.5 \mathrm{~m}$.

\section{a) Physico-Chemical Parameters}

The physicochemical parameters studied on water were temperature (Celsius thermometer scale ranging from $0^{\circ} \mathrm{C}$ to $100^{\circ} \mathrm{C}$ ), water column by rope and scale, Transparency was measured by secchi disc method, $\mathrm{pH}$ by field digital $\mathrm{pH}$ meter, dissolved oxygen by modified Winkler's method (Strickland and Parsons, 1972), alkalinity by titration method, water nitrate $\left(\mathrm{NO}_{3}-\right.$ $\mathrm{N})$ was determined by UV spectrophotometer and phosphate by colorimetric procedure. Silicate was determined by the color of the silicomolybdic acid complex by a Beckman spectrophotometer. Primary productivity was determined by measuring the oxygen produced i.e. photosynthesis by light and dark bottle 
technique. Water samples were collected at monthly intervals from the beel throughout the investigation period. The collected soil samples were brought to the laboratory of Environmental Science, The University of Burdwan, for determining the desired parameters. Soil texture was determined by mechanical analysis as per Piper (1966). Soil pH as determined by the electrometric method using a $\mathrm{pH}$ meter. The nitrogen was estimated by Kjeldahl's method and available phosphorous was determined by Tong's method.

\section{b) Analysis of Plankton}

The plankton samples were collected in the monthly intervals from Bansadaha beel in fixed spots by plankton net made of standard nylon boltting cloth no.25 (mesh size: $0.03-0.04 \mathrm{~mm}$ ). The planktons were preserved in a $3 \%$ formaldehyde solution in $10 \mathrm{ml}$ vials and brought to the laboratory of the Zoology Department, Burdwan University. Quantitative and qualitative analyses of collected samples were done in the laboratory by using a Sedgewick-Rafter counting cell. Identification of planktonic organisms was carried out in the Department of Zoology, The University of Burdwan.

\section{c) Macrophytes}

The samples for biomass analysis were collected at random using one sq.m. quadrate. Freefloating pant materials were collected along with rooted parts, while the submerged plants were uprooted from the enclosed area. The collected materials were transported into the laboratory and were sorted specieswise. The collected macrophytes were identified in the Department of Botany, The University of Burdwan.

\section{d) Fish fauna}

Fish fauna samples were collected every month with the help of local fishermen. Specimen of each species was collected for identification consulting the books of Jayram (1981), Talwar and Jhingran (1991) in the fisheries Laboratory, Department of Zoology, Burdwan University.

\section{RESULTS}

\section{a) Water Temperature}

Variability in water temperature from January to December was not well marked and ranged from 26.2 to 27.5. The temperature being recorded higher during summer and pre-monsoon months (Table 1).

b) $\mathrm{pH}$ :

The $\mathrm{pH}$ value recorded from 7.8 to 8.9 , i.e., no remarkable seasonal variation in the $\mathrm{pH}$ values, was observed (Table 1).

\section{c) Dissolved oxygen}

The dissolved oxygen content ranges from 4.66 $\mathrm{mg} \mathrm{L}^{-1}$ to $7.07 \mathrm{mg} \mathrm{L}^{-1}$. The higher values of dissolved oxygen were recorded from June to September, followed by March to May and October to November (Table 1).

\section{d) Alkalinity}

Higher values of alkalinity was recorded during the summer period (185.2 $\mathrm{mg} \mathrm{L}^{-1}$ ) and lower values during monsoon and winter months (Table 1).

\section{e) Transparency}

Hardly any noticeable fluctuation was observed in the water transparency of the Bansdaha beel during summer and monsoon months, except during winter months (Table 1).

\section{f) Phosphate}

Bansdaha beel exhibited phosphate values between $0.07 \mathrm{mg} \mathrm{l}^{-1}$ to $.35 \mathrm{mg} \mathrm{l}^{-1}$. The seasonal variation showed the presence of higher value, i.e., $0.35 \mathrm{mg} \mathrm{l}^{-1}$ during summer ,i.e., March to May and lower monsoon (0.17 $\left.\mathrm{mg} \mathrm{l}^{-1}\right)$ and winter months $\left(0.07 \mathrm{mg} \mathrm{l}^{-1}\right.$ to $0.15 \mathrm{mg} \mathrm{l}^{-1}$ ) (Table 1).

\section{i. Silicate}

Hardly any seasonal fluctuations were observed in the silicate values in the Bansdaha closed beel (Table 1).

\section{ii. Nitrate}

The nitrate value exhibited higher value $(0.05$ $\mathrm{mg} \mathrm{l}^{-1}$ ) during summer months i.e., March to May and lower $\left(0.02 \mathrm{mg} \mathrm{l}^{-1}\right)$ during the monsoon $\left(0.03 \mathrm{mg} \mathrm{l}^{-1}\right)$ and winter $\left(0.02 \mathrm{mg} \mathrm{l}^{-1}\right)$ months (Table 1).

\section{g) Sediment Characteristics}

i. Soil texture

The Bansdaha, closed beel contains a very high percentage of sand, which is about $93 \%$, silt3\% and clay 4\% (Table 2).

\section{ii. Soil $\mathrm{pH}$}

In Bansdaha, soil $\mathrm{pH}$ exhibited hardly any seasonality with minor higher values during the monsoon and lower values during summer and winter (Table 2). 
Table 1: Physico-chemical parameters of surface water in Bansdahabeel

\begin{tabular}{|c|c|c|c|c|}
\hline Parameters & December-January & March-May & June- September & October-December \\
\hline Water Temperature & $26.2 \pm$ & 27.3 & 27.5 & 26.7 \\
\hline $\mathrm{pH}$ & 7.83 & 8.03 & 7.95 & 7.8 \\
\hline Dissolved oxygen $\left(\mathrm{mg} \mathrm{L}^{-1}\right)$ & 4.66 & 6.31 & 7.07 & 6.35 \\
\hline Alkalinity $\left(\mathrm{mg} \mathrm{l}^{-1}\right)$ & 179.8 & 185.2 & 178.1 & 176.7 \\
\hline Transparency $(\mathrm{cm})$ & 1.03 & 0.72 & 0.75 & 0.73 \\
\hline Phosphate $\left(\mathrm{mg} \mathrm{l}^{-1}\right)$ & 0.15 & 0.35 & 0.17 & 0.07 \\
\hline Silicate $\left(\mathrm{mg} \mathrm{l}^{-1}\right)$ & 2.41 & 2.31 & 2.13 & 2.32 \\
\hline Nitrate $\left(\mathrm{mg} \mathrm{l}^{-1}\right)$ & 0.04 & 0.05 & 0.03 & 0.02 \\
\hline
\end{tabular}

\section{h) Phosphorus}

The available phosphorus content in the bed sediment was found to be higher in summer months and lower in winter and monsoon months $(0.43,0.23$, 0.33 and $0.38 \mathrm{mg} / 100 \mathrm{gm}$ of soil) (Table 2 ).

\section{i) Nitrogen}

The values of available nitrogen of soil sediment were found to be comparatively higher during summer months (10.16 mg/ $100 \mathrm{gm}$ of soil) and marked lower value during the monsoon season $(5.58 \mathrm{mg} / 100 \mathrm{gm}$ of soil) (Table 2).

\section{j) Phytoplankton}

In Bansdaha, closed beel, the highest monthly mean of phytoplankton was observed during June and
July. The phytoplankton population was represented primarily Chlorophyceae, and Cyanophyceae. The dominated species of Bansdaha was Planktosphaeria and Closterium, and Cyanophyceae are dominated by Anabaena and Lyngbya. (Fig. 1)

\section{k) Zooplankton}

The zooplankton population in the Bansdaha closed beel varied from $37 \mu^{-1}$ to $1205 \mu^{l^{-1}}$. The beel showed three peaks during February, July and November. The zooplankton is represented by Cyclops, Diaptomus, Nauplii, and Daphnia. (Fig. 2)

Table 2: Physico-chemical characteristics of soil sediment in Bansdahabeel

\begin{tabular}{|l|c|c|c|c|}
\hline \multicolumn{1}{|c|}{ Parameters } & December- January & March- May & June- September & October- November \\
\hline Sand (\%) & 93 & & & \\
\hline Slit (\%) & 3 & & & \\
\hline Clay (\%) & 4 & & & 6.2 \\
\hline Soil pH & 6.3 & 6.16 & 6.4 & 0.23 \\
\hline Phosphorus (mg 100-1 of soil) & 0.38 & 0.43 & 0.33 & 5.58 \\
\hline Nitrogen (mg 100-1 of soil) & 8.2 & 10.16 & 6.25 & \\
\hline
\end{tabular}

\section{l) Macrophytes}

The Bansdaha beel harboured mixed population of macrophytes. The numbers somewhat higher during the summer months. The marginal macrophytes were restricted to about $8-10 \%$ of water spread and represented by Ceyratia, Cyperusspecies. The rootless floating species like Salvinia notatus, and Azolla sp. and rooted free-floating types like Spirodella polyrhiza, Pistia stratioles. The rooted submerged macrophytes were represented by Ceratophyllum demersum, Hydrilla verticillata and Vallisneria spiralis. The only rooted floating macrophyte Nymphaea sp. was recorded. (Fig.3). m) Fish production

Fish production is found to be 1159.83 $\mathrm{kg} / \mathrm{ha} /$ one year. The production value of carp was $853.19 \mathrm{~kg} / \mathrm{ha} /$ one year. The highest production of fish was recorded during March, April and May. The fish species is represented by Catla catla, Labeo rohita, Labeo bata, Puntius ticto, Amblypharyngodon mola, Channa sp., Anabas testudineus, Notopterus notopterus, Mystus vittatus, Mastocembelus armatus, and Heteropneustes fossilis. (Fig. 4). 


\section{Discussion}

The basic understanding of the limnology, productive potentials, and fish populations of beel is very essential for the sustainable development of beel fisheries (Tamuli et al. 2018). The closed beel is the disconnected remnants of tributaries of riverine networks. Due to topographical feature, the fluctuation in the water column on an average ranged from 1.75 to $5.5 \mathrm{~m}$ in Bansdaha. According to Mukhopadhyay (1997), the beels of West Bengal are vulnerable to high water level fluctuation. This probably facilitates the growth of rooted aquatic macrophytes that compete for nutrients with phytoplankton. The low transparency has been observed during summer months, which is attributed to the wind action and phytoplankton bloom. Similar seasonal fluctuation in lakes has been reported by Kumar (1985) and Nath (1999). In the present study, the surface water temperature in Bansdaha varied from 26.2 to 27.5. However, the higher temperature was recorded during the summer and monsoon months. Similar sort of temperatures of the water surface was reported by Bhowmik (1988) and Bhattacharya (2010) and Kapil (2010) in beels and bars of west Bengal. In the present observation, the concentration of hydrogen ion was slightly alkaline. The alkaline $\mathrm{pH}$ of the water body revealed high productivity and also a conductive environment for bio-community habitation and multiplication. Banerjee (1967) observed that a pH of 8.0 and above had been recorded to be productive. A slightly alkaline water $\mathrm{pH}$ was optimum not only for the fishes but also for fish food organisms. Sivlingam et al. (2013) reported that $\mathrm{pH}$ is positively correlated with alkalinity, dissolved oxygen, and phosphate. The highest concentration of dissolved oxygen content from June to September in Bansdaha, possibly because of rainfall and alkaline $\mathrm{pH}$, the decomposition of organic matter was less with low consumption of dissolved oxygen. The main supply of phosphorus in the water body comes from leaching of the soil of the catchment area by rain. The values of phosphate of the present study were higher in the summer season, which indicated highly productive. The nitrate concentration was optimal for the growth of plankton. In the present study, the concentration of silicate varied minutely. Silicate content in the water body is of immense significance as a major nutrient for diatoms (Chakrabarti, 1980).

The soil texture contains a high percentage of sand, and a low percentage of silt and clay in Bansdahabeel indicate rich productivity. The soil pH is acidic in nature. Das (1983), working on the bells of West Bengal, has reported a similar acidic pH of soil. In the soil sediment, low phosphate content may be the fact that phosphate ion in soil form soluble compound with iron and aluminum and with calcium under alkaline condition. The plankton population was the major contributor in the Bansdahabeel. The nitrate and phosphate content of water influence the seasonal changes of phytoplankton in the beel (Toner 1981). Highest Cyanophyceae was found to be a major contributor among the phytoplankton in Bansdahabeel. The present study corroborates with the findings of Bhaumik (2001). Zooplankton was found to be inversely correlated with phytoplankton in Bansdahabeel. A similar sort of positive correlation between zooplankton and phytoplankton was reported by McCauley and Kalft (1981).

In the present investigation, the Bansdaha beel harboured mixed population of macrophytes with the dominance of submerged plants. However, deeper parts of the beel were found to be scarcely infested due to depth differences. The rooted submerged macrophytes was found to be more than the other groups. Sharma (1995) also recorded dominance of submerged macrophytes in Kawar Lake in Bihar and opined that this might often result in siltation.

The Bansdahabeel is represented by 12 to 15 dominant species of ichthyo fauna. Bhowmik (1988) and Sugunan et al. (2000) emphasized that the combination of Indian and exotic carps greatly influences fish production in the beels. Fish production in Bansdaha beel was found to be highly correlated with phytoplankton and total plankton.

Therefore, the Bansdaha beel is ideal for practicing culture-based Fisheries as this beel is very rich in nutrient and fish food organisms. The beel also allows the stocking of detritivorous fishes as the energy transfer takes place through the detritus chain. At present, the beel urgently require renovation and proper financial assistance and guidance from the Government sector are essential in this regard. Many species of fishes of Indian origin have become extinct, and many are on the verge of extinction. Bells are suitable places for harboring and culturing such rare species as beels contain several naturally occurring niches. On $11^{\text {th }}$ September 2019, the honorable minister, Sri. Swapan Debnath, Animal Resources Development Ministry, Govt. Of West Bengal, along with the administrators of Panchayet and zilla parishad planted various types of trees on the dike of beel to save greenery as well as to keep the environment viable.

\section{ACKNOWLEDGMENT}

The author is thankful to Prof. A.R. Ghosh of the Department of Environmental Science, Mr. Mainak Banerjee of Department of Zoology, Prof. Tusharkanti Maiti, Department of Botany of The University of Burdwan.

\section{References Références Referencias}

1. Banerjee, S.M. 1967. Water quality and soil condition of fish ponds in some states of India in 
relation to fish production. Indian J. Fish., 14(182): 115-144.

2. Bhattacharya, K.G., N.Kapil, 2010. Inpact of urbanization on the quality of water in a natural reservoir: A case study with the deeper beel in Guwahati city, India. Water and Env. J., 24:83-96.

3. Bhaumik, U. 2001. Ecodynamics and fisheries management of some beels and its impact on the socio-economic status of the operatives in West Bengal. Kurukshetra University, Kurukshetra, 308 pp.

4. Bhowmik, M.L. 1988. Limnology and productivity of some beels and baors of West Bengal with reference to recent development. Environ. \& Ecol., 6(1): $42-47$.

5. Chakrabarti, P. 1980. Studies on the hydrobiology of some freshwater fisheries. Ph.D. Thesis, Burdwan University, India. 251pp.

6. Das, P.K.1983. A model for upper tertiary sedimentation of Arunachal Predesh with special reference to Subansiri district. J. Assam Sci. Soc. 25(2): 66-69.

7. Jayram, K.C.1981. The freshwater fishes of India, Pakistan, Bangladesh, Burma and Srilanka, Hand book of Zoological Survey of India.

8. Kumar, K. 1985. Hydrobiological investigations of a freshwater beel with special reference to its fish production potentialities. Ph.D. Thesis, Bhafgalpur University, Bihar, India.

9. McCauley, E. and J. Kalff, 1981. Emperical relationships between phytoplankton and zooplankton biomass in lakes. Can. J. Fish. Aquat. Sci., 38(4): 458-463.

10. Mukhopadhyay, M.K. 1997. Ecology of the beels in West Bengal. In: Fisheries enhancement of small reservoirs and floodplain lakes in India. Eds. V.V. Sugunan and M. Sinha. CIFRI Bull. 75:187-190.

11. Nath, D. 1999. Role of biotic factors in management of fisheries in open water system, In: Open water fisheries technologies and extension methods, CIFRI Bull. 96: 86-90.

12. Piper, C.S.1966. Soil and plant analysis. Hans Publishers, Bombay, $368 \mathrm{pp}$.

13. Sharma, U.P. 1995. Role of macrophytes in the ecosystems of Karwar Lake wetland (Begusarai). J. Freshwater Biol., 7(2): 123-128.

14. Sinha, M. 1997. Floodplain wetlands, an important inland fishery resources of India. Aquae. Asia, 2(4): 8-10.

15. Sinha, M. 1998. Wetlands and their implications on fisheries. Meenbarta, Dept. of Fisheries, West Bengal, p. 11-14.

16. Sinha, M. 2001. Reservoir and important fishery resources of India and its utilization for increasing fish production in the country. CIFRI Bull., 106: 1-15.
17. Sivalingam, P., M. Swamy and R.T. Reddy, 2013. Zooplankton diversity with reference to the physicochemical parameters of Kaijjarla Lake, Adilabad district, Andra Pradesh. Indian Inst. Res. J. Biol. Sci., 2(1): 24-28.

18. Sugunan, V.V., G.K. Vinci, B.K. Bhattacharya and A. Hassan, 2000. Ecology and fisheries of beels in West Bengal. CIFRI Bull., 103: 53.

19. Talwar, P.K. and A.G. Jhingran, 1991. Inland fishes of India and adjacent countries. Oxford and IBH, New Delhi.

20. Tamuli, P., S.K. Bhagabati, R.Dutta. A.S.N. Zaman, J.Sarma, A.Choudhury, Mudoi, L.P. and D.J. Debnath, 2018. Physico-chemical characteristics of 47 nos.Morakolongbeel, Morigaon district, Central Brahmaputra Valley zone, Assam. Int. J. Chemical Stud. 6(5):748-754.

21. Toner, R.C. 1981. Interrelationships between biological, chemical and physical variables in mount Hope Bay. Massachusetts, USA. Estuarine Coastal Shalf Sci., 12(6): 701-712.

22. Yadav, Y.S.1987. Studies on the Limnology and productivity of an Oxbow lake in Dhubri district of Assam. Ph.D. Thesis, Guwahati Univ., Assam. Pp 320. 


\section{LEGENDS OF THE FigURES}

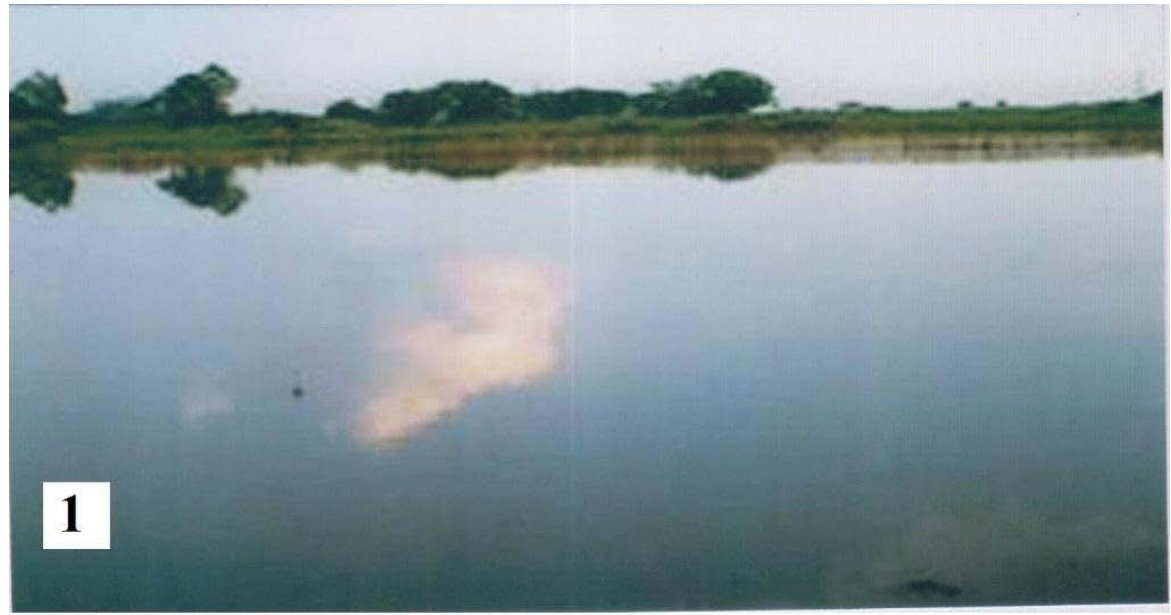

Fig. 1: Picture of the experimental site, Bansdahabeel.

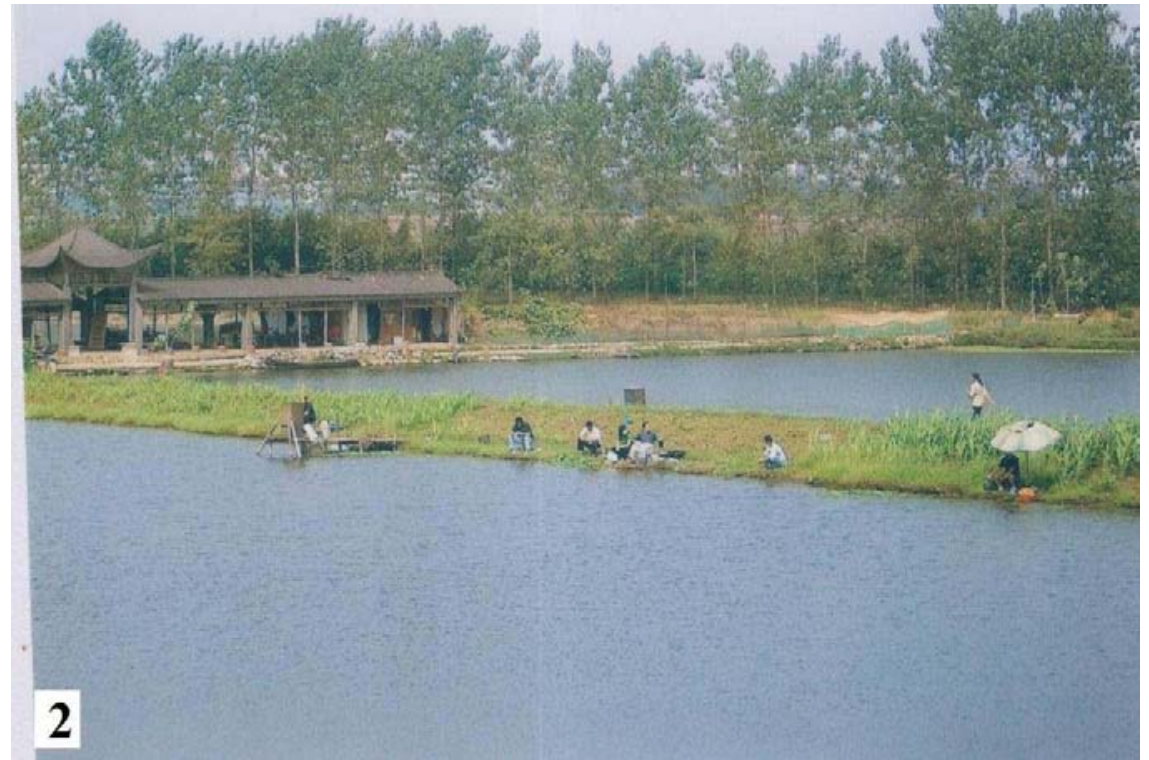

Fig. 2: Estimation of Zooplankton population in the experimental site.

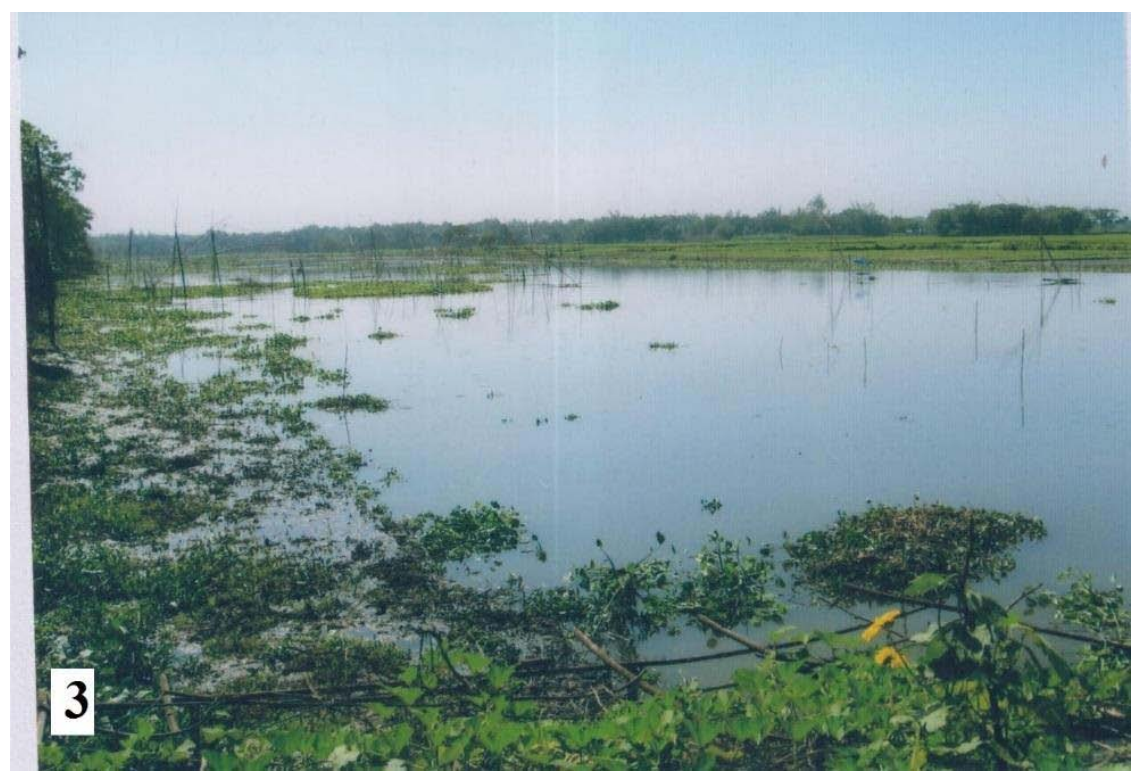

Fig. 3: Distribution of mixed population of marcrophytes in Bansdahabeel. 


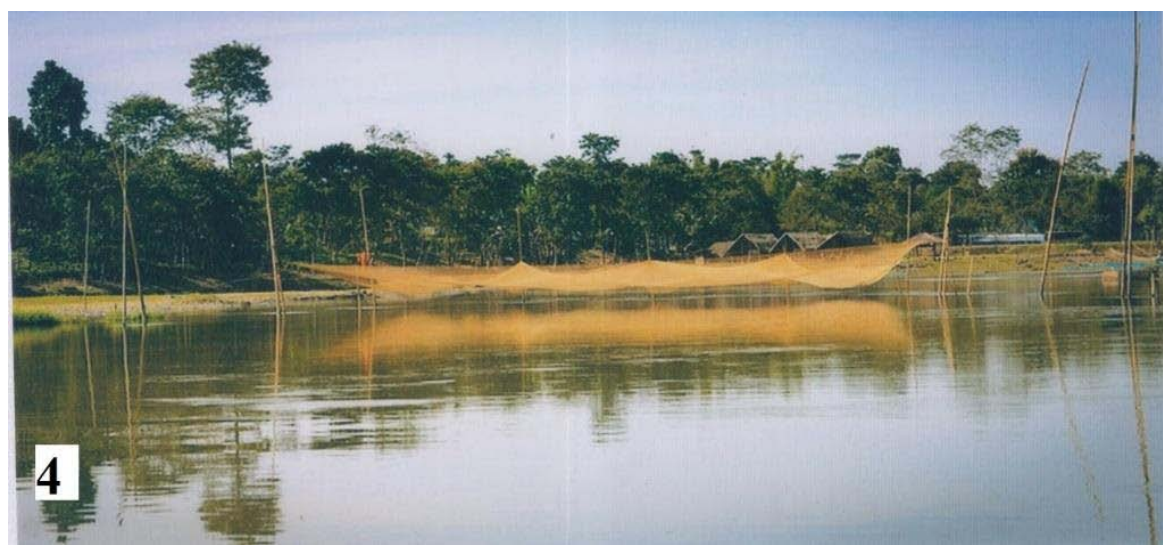

Fig. 4: Figure showing the main culture and collection zone for vaious type of fish species. 